\title{
Real Estate Investment Efficiency and Monetary Policy
}

\author{
Yuxin Ning \\ Economics and Management school \\ Xi'an Shiyou University \\ Shannxi P. R. China,710065 \\ Email: nyx91@sina.com
}

\author{
Feifei Li \\ Economics and Management school, \\ Xian Shiyou University \\ Shannxi P. R. China,710065 \\ Email: Lifeifei@sina.com
}

\begin{abstract}
This paper mainly studies the impact of China's macroeconomic policies (monetary policy) on the efficiency of investment in real estate listed companies. Based on real estate listed companies as the research object, within the 2008-2009 years of time window, this paper examines the relationship between monetary policy and the excessive investment based on the Richardson (2006) model. The results show that China's state-owned holding listed companies generally have excessive investment behavior and invest too much greater degree than the private listed companies. And further, tight monetary policy and the investment efficiency of state-owned holding listed companies have significantly negative relationship. In the tight monetary policy period, state-owned holding listed companies still exists over investment behavior. This paper's policy implication is that deflating macroeconomic regulation should consider the differences of micro entity background, otherwise, the macroeconomic regulation' efficiency and effective should be discounted.
\end{abstract}

Keywords- monetary policy; currency deflation; investment efficiency; over-investment

\section{INTRODUCTION}

Monetary policy is the important macroeconomic regulation in our country, and it would have important impact on the firm's financial policy. From the next half year of 2008, international financial crisis give rise in the globe financial shaking and loan shrinking. In order to avoid the risk of economic slipping down our government timely adjusted the tight monetary policy to moderately relaxed monetary policy. This adjustment has got instant results. The volume of money in circulation increased by $27.7 \%$ and $\mathrm{RMB}$ loans increased 9.59 billion RMBs. On the background of monetary regulating policy, different nature enterprises have got different effects. For example, the stated enterprises are easier to get loan than private enterprises, and would have less been influenced by international financial crisis. However, it should be considered that whether the stated enterprises would have a good efficiency when they could obtain support from government. This problem would help us understand the effects of macroeconomic regulation policy on the micro enterprises which could check our implementation impact of macroeconomic policy.

Old past research about firm's investment efficiency mainly focus on the company level and least involved in the macroeconomic policy. As we consider, the investment behavior of enterprises is not only influenced by the firms' free cash flow, financial constraints and corporate government, but also is influenced by macroeconomic policy. Therefore, it is value and meaningful to combine macroeconomic factors with micro factors to study on enterprises' investment efficiency. Based on above reasons, this paper chooses 2008 -2009 as time windows and chooses real estate enterprises as research samples to study investment efficiency being combined macro economical factors with micro factors. The paper's structure as follows: the second part is about literature review, the third part is about system background and research hypothesis, the fourth part is about research design, the fifth is about the empirical result analysis, the last is about research conclusion and policy suggestion.

\section{LITERATURE REVIEW}

Jensen and Ruback(1983) considered that investment efficiency would increase firm value and influence the enterprise development.Investment efficiency is influenced by enterprise's free cash flow, financing constraint and corporate government . Liuchangguo's research shows that owing to unsymmetrical information between shareholders, creditors and management, adverse selection and moral hazard would give rise to some agent problems and lead to investment inefficiency. On the other hand, some researchers also found that debt financing had some control role on monitoring management and could increase investment efficiency(Jensen, 1986). YuDongZhi(2003), JiangWei(2004) and YuMingGui (2008) found that in our country the listed company's capital structure had an negative relationships with the firm's profit, which illustrated that in the listed companies , debt financing didn't play a positive role in controlling overdue investment.

Overall, past research about investment efficiency focused on the firm's self-factors, ignoring exterior factors , such as macro-economic influences.

Monetary policy would influence the micro-firm's economic behavior through causing the mediator variables of economic system changing. There are two basic channels of transmission of micro-economic policy: one is monetary transmission channel, including rate, assets price and exchange rate channel. The other is credit channel, including bank loans and asset-liabilities channel. Keyesianism thinks that rate is the core of monetary policy. The firm's investment 
is determined by relationship between margin profit and capital cost. Tobins' theory explains the monetary policy transmission mechanism and think that the change of rate would influence the anticipated profit and discounted cash flow. Ben S.Bernank and Mark Gertler(1995)' researches shows that monetary not only influences the level of rate but also changes the financial intermediary's credit supply, which all influences the capital cost. Therefore, macro economic policy has close relationship with the firm investment. The paper is based on above theories to study on the macro-policy's effect on the firm investment.

It is always a heat problem how to measure investment efficiency. Some index includes average Tobin's rate, the rate of capital cost to investment return and so on. In this paper, we would make use of Richardson (2006) model to study on the macro -policy 's effect on the firm investment.

\section{ANALYZING IMPACT OF MONETARY POLICY ON INVESTMENT}

According to monetary economic policy, when monetary authority adopts contract policy, the rate of capital would rise and the cost of capital would also rise, which gives rise to decrease of investment level and production amount. For most enterprises, lots of expenditures are rigid, including amortization or depreciation charge of amounts of capital investment, worker salary and necessary operating expenses. With shrinking of monetary policy, firm's investment efficiency would decrease because firm could not adjust sales price and some rigid expenses. However, we should see that dual economic structure widely exists which lead to the distortion of financial and could not realize the marketization of financial markets. According to the definition of Zhutong (2010), the distortion of financial refers to principal owners and subordinate owners difference, local loan ration difference and rate regulating. During the timing window of monetary policy adjustment, the distortion of finance is obvious, that is amounts of superior financial resources would be prior to allocate to the stated enterprises which have the government support. Yekangtao(2009)finds that during 2004-2007, non-state owned enterprises obtained minor loan capital when monetary authorities adopted shrink policy. On the other hand, under the separation of power between the local government and central government, government at all levels intervene local economic activities directly or indirectly, the stated-owned enterprises undertake the political objective of promoting the growth of local economic (Huang Liangjie,2010). The background difference between stated-owned enterprises and private enterprises leads to different financial limitation. Therefore, even if all enterprises face the shrink monetary policy, the stated-owned enterprises enjoy priority of loan allocation. However the soft financial constraints would decrease the efficiency of invest-ment, which refers to overdue invest-ment, Based on above the theory analysis, we could propose two hypothesis

One hypothesis: relative to private-owned enterprises, the state-owned enterprises has low investment efficiency.

Second hypothesis: relative to stated-owned enterprises, the adjustment of monetary policy has more effect on investment efficiency of private-owned enterprises.

\section{RESEARCH DESIGN}

\section{A. Sample Choosing}

The paper chooses real estate listed companies as research samples, and choose 2008-2009 as timing window. Real estate listed companies are capital-intensive industry, which is easy to be influenced by micro-economic policy. Loose or shrink monetary policy, the rate being increased or decreased all would influence the investment change of real estate industry. Therefore, choosing real estate listed companies is representative. In order to ensure accurate empirical results, samples are dealt with as following:

(1)In order to avoid influences of abnormal data, ST, PT listed companies are got rid of , including some companies with incomplete data.

(2) Some companies which has high financial risk are also got rid of .

(3) In order to ensure results of robustness, some succession date has been winsorized under one percent of level .

Through above the treatment, we obtain 117 samples. And all date come from the Shanghai stock exchange and the Shenzhen Stock Exchange Web site. All statistics results are given by Eviews 6.0.

\section{B. Definition of Variables}

The paper mainly study on influences of micro-economic on enterprises investment efficiency, particularly caring about the different effect between stated-owned enterprises and private-owned enterprises. Therefore, the paper chooses listed companies' investment efficiency as explained variables, Dependent variables include macro-adjusting variable and the firm nature. Control variables include the firm' growth , debt ratio, cash holdings, the years of the listed companies, the firm size and so on. All variables are listed in Table 1.

TABLE I LISTING OF VARIABLES

\begin{tabular}{ll}
\hline & Variables \\
\hline Independent variables & Newinvt \\
& Invt \\
\hline Dependent variables & Nature \\
& MP \\
\hline Control variables & Grow \\
& Lev \\
& Cash \\
& Age \\
& Size \\
& Return \\
& Newinvt_lag \\
& CF \\
& Sales \\
\hline
\end{tabular}

\section{Setting Regression Model}

This paper chooses Richardson (2006) residual model which not only distinguish whether the firm is in overdue-investment or insufficient investment ,but also could measure the level of overdue investment and insufficient investment.

Firstly , we regression 2008-2009 data and use the regression residual as the index of investment efficiency, that 
is invt, which represents the differences between the practical investment and ideal investment. If the index is positive, which illustrates that investment efficient is low , the more the index is , the lower investment efficiency is . the model is set as (1)

$$
\begin{array}{r}
\text { Newinvt }_{\mathrm{i}, \mathrm{t}}=\beta_{0}+\beta_{1} \mathrm{Grow}_{\mathrm{i}, \mathrm{t}-1}+\beta_{2} \mathrm{Lev}_{\mathrm{i}, \mathrm{t}-1}+\beta_{3} \operatorname{Cash}_{\mathrm{i}, \mathrm{t}-1}+\beta_{4} \mathrm{Ag} \\
\mathrm{e}_{\mathrm{i}, \mathrm{t}-1}+\beta_{5} \text { Size }_{\mathrm{i}, \mathrm{t}-1}+\beta_{6} \text { Return }_{\mathrm{i}, \mathrm{t}-1}+\beta_{7} \text { Newinvt_lag }_{\mathrm{i}, \mathrm{t}-1}+\varepsilon_{\mathrm{i}, \mathrm{t}}
\end{array}
$$

In our model , the independent variable is lagged behind dependent variables one time. $\beta_{0}$ represents constant term, $\beta_{1-} \beta_{7}$ represents coefficient. The paper includes 117 samples, and state-owned firms account for $47 \%$, non-stated owned firms account for $53 \%$.

Table 2 lists the testing result of listed company's newly-increased investment. There is good fitting effect and each variables'coefficient is outstanding. From the testing result , 61 listed companies are overdue investment in 2008, and 31 listed companies are overdue investment in 2009.

TABLE II EMPIRICAL RESULTS FOR NEW INVESTMENT OF LISTED COMPANIES

\begin{tabular}{cccccccccc}
\hline year & cons & $\begin{array}{l}\text { Gro } \\
\text { w }\end{array}$ & $\begin{array}{l}\text { Lev } \\
\end{array}$ & $\begin{array}{l}\text { Cas } \\
\text { h }\end{array}$ & Age & Size & $\begin{array}{l}\text { Ret } \\
\text { ern }\end{array}$ & $\begin{array}{l}\text { Ne } \\
\text { win }\end{array}$ & $\begin{array}{l}\text { Adju } \\
\text { sted } \\
\text { R2 }\end{array}$ \\
\hline 08 & -0.18 & 0.00 & -0.03 & 0.15 & 0.00 & 0.00 & -0.0 & 1.19 & 0.95 \\
& 61 & 04 & 04 & 64 & 60 & 52 & 003 & 38 & 44 \\
& -6.52 & 1.96 & -3.37 & 8.28 & 11.3 & 4.24 & -3.0 & 23.9 & \\
& $86^{*}$ & $91^{* *}$ & $49^{*}$ & $81^{*}$ & $679^{*}$ & $49^{*}$ & 332 & $587^{*}$ & \\
\hline 09 & 0.08 & 0.00 & -0.01 & 0.11 & -0.0 & -0.0 & 0.0 & 0.10 & 0.70 \\
& 16 & 65 & 14 & 72 & 001 & 034 & 001 & 39 & 01 \\
& 4.85 & 6.22 & -1.86 & 7.43 & -0.2 & -4.2 & 0.4 & 3.98 & \\
& $02^{*}$ & $26^{*}$ & $42^{* *}$ & $58^{*}$ & 645 & $256^{*}$ & 043 & $32^{*}$ & \\
\hline
\end{tabular}

*significant over $1 \%$, **significant over $10 \%$

\section{EMPIRICAL RESULTS ANALYSIS}

\section{A. Model Choosing}

The paper is based on Richardson (2006) model and constructs the following model (2) by utilizing the positive residual invt from model (1) :

$$
\begin{gathered}
\operatorname{Invt}_{\mathrm{i}, \mathrm{t}}=\beta_{0}+\beta_{1} \mathrm{Natu}_{\mathrm{i}, \mathrm{t}}+\beta_{2} \operatorname{Lev}_{\mathrm{i}, \mathrm{t}}+\beta_{3} \mathrm{Grow}_{\mathrm{i}, \mathrm{t}}+\beta_{4} \mathrm{CF}_{\mathrm{i}, \mathrm{t}}+\beta_{5} \mathrm{Sal} \\
\mathrm{es}_{\mathrm{i}, \mathrm{t}}+\beta_{6} \operatorname{Size}_{\mathrm{i}, \mathrm{t}}+\varepsilon_{\mathrm{i},}
\end{gathered}
$$

In the model (2), $\beta_{0}$ represents constant term , $\beta_{1-} \beta_{6}$ represents coefficients. If hypothesis 1 is set up, the sign of $\beta 1$ should be positive according to the research of Ahn(2006), Firth(2008), Jiang Wet and Libin and so on.

To test empirically the relationship of monetary policy and state-owned enterprises investment efficiency, we introduce the dummy variable in model (2) and construct the following model (3):

$$
\begin{array}{r}
\operatorname{Invt}_{\mathrm{i}, \mathrm{t}}=\beta_{0}+\beta_{1} \mathrm{MP}_{\mathrm{i}, \mathrm{t}}+\beta_{2} \mathrm{MP} \times \mathrm{Natu}_{\mathrm{i}, \mathrm{t}}+\beta_{3} \mathrm{Natu}_{\mathrm{it}}+\beta_{4} \mathrm{Lev}_{\mathrm{i}, \mathrm{t}} \\
+\beta_{5} \mathrm{Grow}_{\mathrm{i}, \mathrm{t}}+\beta_{6} \mathrm{CF}_{\mathrm{i}, \mathrm{t}}+\beta_{7} \mathrm{Sale}+\beta_{8} \mathrm{Size}+\varepsilon_{\mathrm{i}, \mathrm{t}}
\end{array}
$$

In the model (3), $\beta_{0}$ represents constant term . $\beta_{1-} \beta_{6}$ represents coefficients. hypothesis 2 is set up, the sign of $\beta 2$ should be prominently negative.

\section{B. Empirical Testing Results}

The regression results are listed in table 3 . From the empirical testing results, we could find that the two models are dominated overall and there is high R2 and adj- R2. which illustrates that all independent variables could explain dependent variables. And DW is close to 2, which illustrates that there is no auto-correlation in varies. On the other hand, all independent variables have dominated $t$ statistical variables.

In the left of table 3 , empirical testing result about hypothesis 1 is listed. From the result, we could find the coefficient of Natu is 0.0256 , and the sign is positive which is dominated in level of $1 \%$, which illustrates that there are widely over-investments in state-owned enterprises,and relative to non-stated enterprises, the extent of overinvestment of state-owned enterprises is greater. Which supports the hypothesis 1 . The results shows that there is low invest efficiency in state-owned enterprises. In table 3, we could see the coefficient of Lev is -0.0976 , which illstrates that if there is high leverage, the extent of over investment is low and there is high investment efficiency. Which supports Jensne (1986) points and is consistent with Aivazian (2005), Ahn(2006) and Fith (2008. The results illustrate that bank loans have some control effects on the listed companies' investment. The coefficient of Grow is 0.0263 and statistically significant at the $1 \%$ level which illustrates that there are more over-investment behaviors for high-growth companies. The coefficients of CF and Sales are respectively -0.0014 and -0.0006 statistically significantly at the $1 \%$ level which illustrates that there is much cash and revenue, there are fewer investments. The coefficient of Size is 0.0060 statistically significantly at the $1 \%$ level which illustrates that there is more investment for larger enterprises.

The right of table 3 lists the empricial testing results. The coefficients of $\mathrm{MP}{ }^{\times} \mathrm{Natu}$ is negative statistically significant at $5 \%$ level, which illustrates that shrink monetary policy doesn't constraints the investment behavior of stated-owned enterprises. During the term of shrink monetary policy, stated-owned enterprises still have many over investments. This result surpports hypothesis2.

Relativly to non-stated-owned enterprises,there is soft budget in stated-owned enterprises and these enterprises are not limited to fiancing.

TABLE III EMPIRICAL OF TESTING

\begin{tabular}{c|c|l|c|c|c}
\hline \multicolumn{3}{c|}{ Model II } & \multicolumn{3}{c}{ Model II } \\
\hline Variables & slop & $\mathrm{T}$ & $\begin{array}{l}\text { Variable } \\
\text { s }\end{array}$ & slop & $\mathrm{T}$ \\
\hline C & $\begin{array}{c}-0.027 \\
1\end{array}$ & -0.63 & $\mathrm{C}$ & $\begin{array}{c}-0.097 \\
3\end{array}$ & $-2.57^{* *}$ \\
\hline Natu & 0.0256 & $5.56^{* * *}$ & MP & 0.0376 & $7.51^{* * *}$ \\
\hline Lev & -0.097 & $-7.08^{* * *}$ & MP $\times \mathrm{N}$ & -0.024 & $-2.16^{* *}$ \\
& 6 & & atu & 7 & \\
\hline
\end{tabular}




\begin{tabular}{|c|c|c|c|c|c|}
\hline Grow & 0.0263 & $5.30^{* * * *}$ & Natu & 0.0338 & $6.66^{* * * *}$ \\
\hline $\mathrm{CF}$ & $\begin{array}{c}-0.001 \\
4\end{array}$ & $-5.45^{* * * *}$ & Lev & $\begin{array}{c}-0.105 \\
5\end{array}$ & $-9.26^{* * *}$ \\
\hline Sales & $\begin{array}{c}-0.000 \\
6 \\
\end{array}$ & $-5.08^{* * * *}$ & Grow & 0.0353 & $10.09^{* * * *}$ \\
\hline \multirow[t]{3}{*}{ Size } & 0.0060 & $2.89^{* * * *}$ & $\mathrm{CF}$ & $\begin{array}{c}-0.000 \\
9\end{array}$ & $-4.82^{* * * *}$ \\
\hline & & & Sales & $\begin{array}{c}-0.000 \\
4 \\
\end{array}$ & $-2.26^{* * *}$ \\
\hline & & & Size & 0.0081 & $4.40^{* * * *}$ \\
\hline \multicolumn{2}{|c|}{ Adjusted R-squared } & 0.9285 & \multicolumn{2}{|c|}{$\begin{array}{c}\text { Adjusted } \\
\text { R-squared }\end{array}$} & 0.9979 \\
\hline \multicolumn{2}{|c|}{ F-statistic } & 167.732 & \multicolumn{2}{|c|}{ F-statistic } & 4549.252 \\
\hline \multicolumn{2}{|c|}{ Prob(F-statistic) } & 0.000 & \multicolumn{2}{|c|}{ Prob(F-statistic) } & 0.0000 \\
\hline
\end{tabular}

*significant over $1 \%$, **significant over $10 \%$

\section{CONCLUSION}

The paper studies the impact of China's macroeconomic policies (monetary policy) on the efficiency of investment in real estate listed companies. Based on real estate listed companies as the research object, within the 2008-2009 years of time window, this paper examines the relationship between monetary policy and the excessive investment based on the Richardson (2006) model. The results showed that overall, China's state-owned holding listed companies generally have excessive investment behavior and invest too much greater degree than the private listed companies. In the tight monetary policy period, state-owned holding listed companies still exist over investment behavior. This paper's policy implication is that deflating macroeconomic regulation should consider the differences of micro entity background, otherwise, the macroeconomic regulation's efficiency and effective could be discounted.

\section{REFERENCE}

[1] Baker,M.,and.Wurgler,2002,"Marker Timing and Capital Structure”. Journal of Finance 57,1-32.

[2] Aivazian V., Y.Ge and J.Qiu,2005,"The Impact of Leverage on Firm Investment: Canadian Evidence," Journal of Corporate Finance,11,pp.277-291.

[3] KornaiJ.,E.MaskinndG.Roland,2003,"Understanding the Soft Budget Constraint,” Journal of Economic Literaturn,41,pp.1095-1136.

[4] La Porta R. ,Lopez de Silanes and F.A.Shleifer,2002,"Government Ownership f Banks,” Journal of Finance,57,pp.265-301.

[5] Lang. fek and and R.M.Stulz,1996,"Leverage, Investment and Firm Growth.,” Journal of Financial Economics,40,pp.3-29.

[6] Modigliani F and M.H.Miller,1958,"The Cost of Capital, Corporation Finance, and the Theory of Investment, "American Economic Review,53,pp.433-443.

[7] Richardson S.,2006, “Over-investment of free cash flow,” Review of Accounting Studies,11,pp.159-189.

[8] Sapienza P.,2004,“The Effects of Government Ownership on Bank Lending,” Journal of Financial Economics,72,pp.357-384.

[9] Jensen M.C.,1986,“Agency Costs of Free Cash Flow, CorporateFinance, and Takeovers," American Economic Review,76,pp.323-329.

[10] FirthM., C. Lin and S.Wong,2008,"Leverage and Investment under a State-owned Bank Lending Environment: Evidence from China," Journal of Corporate Finance,14,pp.642-653.

[11] Ahn..J.Denisand D.K.Denis,2006," "Leverage and Investment in Diversified Firms,” Journal of Financial Economics,79,pp.317-337. 289-323. 